










\section{Raise Awareness}

While not very common, some students $(6 \%, \mathrm{n}=22)$ pointed out that their biggest concern was to raise awareness of climate change. Some of these students seemed to have a clear picture of how to achieve this but needed support, whereas others saw raising awareness as an important goal but were still seeking ways to do so. A personal approach to raising awareness was presented by a 19-year-old female from Europe. She wondered:

How can I convince my friends and family to save energy, use less water, segregate rubbish etc.?

Whereas, a 16-year-old female student from Europe took a broader perspective:

I want to discuss how we can conceptualize the combination of lectures, workshops, panel debates, educational role-play games and other different program elements, as well as youth participation in promoting street action for climate change. How youth can participate in the delineation of national reform policies for youth and integrated social support for vulnerable adolescents and adolescents from vocation schools.

\section{Statistical analysis}

Correlation between the groups was examined, and the Climate System Framework was found to have a weak negative correlation with the categories Raise Awareness $(\rho=-0.190, p<0.01)$ and Human Action $(\rho=-0.239, \mathrm{p}<0.01)$. Though the differences between gender, continent of origin and age were analysed with the Mann-Whitney U test, differences were only found in the category Climate System Framework, in which the male students were significantly more interested $(\mathrm{n}=48,41 \%)$ in these issues than female students $(52 \%, \mathrm{n}=69), \mathrm{Z}(1, \mathrm{n}=117)=-2.484, \mathrm{p}<.05$.

\section{DISCUSSION}

The climate change related questions analyzed in this study shows that, although the students participating in the study were all interested in climate change, there was great variation in their areas of interest, regarding the topic. In essence, the multidisciplinary and complex nature of climate change is reflected in the students' questions. Furthermore, in alignment with previous research (e.g. Tirri, Tolppanen, Aksela \& Kuusisto, 2012), the findings indicate that even in a scientific context, students do not ask questions merely related to science: on the contrary, students ask a wide range of questions, ranging from politics to psychology and from economics to individuals' behavior. Educational researchers (e.g. Schreiner et al., 2005) have discussed the importance of bringing the multidisciplinary nature of climate change into education and the findings of this study indicate that, at best, a multidisciplinary approach can be achieved by addressing students' questions on climate change. How these questions could be addressed to support systems thinking and a holistic view of climate change will be discussed below in further detail.

\section{Addressing Students' Questions Holistically}

The students' questions show that they want answers to many of the same climate change issues that educational researchers have said should be implemented into climate change education (see Shepardson et al. 2012; Svihla \& Linn, 2012; Schreiner et al., 2005). However, as the questions presented by the students are multifaceted, answering the questions requires understanding of climate change from many different perspectives. These aspects include at least scientific, technological, 
societal, individual and ethical aspects and how these aspects are linked to each other. Nonetheless, students' questions should be addressed holistically, rather than through simple truths, in order for them to gain an understanding of the multifaceted nature of climate change and enhance their skills in systems thinking. The following section discusses why and how this could be done from several different viewpoints.

\section{Addressing Scientific Aspects:}

The results of this study show that students want to understand the physical phenomena behind climate change, the research methods used and how trustworthy the results are. This interest towards the science of climate change was especially apparent in male students. Shepardson et al. (2012) have presented the Climate System Framework as a guideline of the scientific aspects that students should know about climate change, in order to understand the environment as a system. Based on the findings of this study, understanding this framework is crucial in answering students' questions.

However, in addition to the Climate System Framework, answering students' questions requires understanding of the nature of science (NOS), as only this will make it possible to answer questions related to climate change research and the trustworthiness of scientific findings. Hodson $(2008,2011)$ has highlighted the importance of teaching about the trustworthiness of scientific research, the nature of science and socio-scientific issues in general. However, the importance of such discussions in a climate change context have not yet received much attention. As the data collected in this study shows that questions related to NOS occur naturally in the context of climate change, climate change education would seem to be a suitable context for NOS discussion. However, earlier research in another context has shown that increased understanding of NOS does not seem to correlate with making more informed decisions about scientifically based personal and societal issues (Bell \& Lederman, 2003). Therefore, implementing NOS into climate change education should not be seen as an easy solution to develop students decision-making skills, but rather, as a tool to help them understand the trustworthiness of science, enabling them to better evaluate statements made of climate scientists and climate change denialists.

\section{Addressing Technological Aspects:}

Students' questions suggest that they are interested in learning about new technological innovations and renewable energy, and how their adoption contributes to climate change mitigation. To address these questions, examining innovative technologies would seem to be of interest to some students. However, from the perspective of systems thinking, in addition to understanding how the technology works, it would be important to understand its role in society from a broader perspective. The reason for this is that history has shown that mere technological innovations do not solve environmental problems (Commoner, 1972; Ehrlich \& Holdren, 1971).

To understand technology's role in society, at least the role of price, subsidies and consumption should be considered. As an example, for a new technology to be adopted, the price needs to be competitive. This may require government support, such as subsidies (Goldberg, 2001), requiring a political decision-making process. Furthermore, technological advancements can have an increasing effect on consumption (Hynes, 1993), reducing the total benefit gained from adopting the technology. Because of such feedback loops, when considering the environmental impact or benefits of a new technology, it is not enough to consider the technology as a lone entity, but other factors, such as population size and consumption should also to be considered (see Ehrlich \& Holdren, 1971).

\section{Addressing Societal Aspects:}


Many participants asked questions on Solutions to climate change, Effects on humans, and Human action. To answer these questions, several societal aspects, such as politics and economics, should be considered simultaneously.

Hynes (1993) and many others have argued that in order to overcome climate change, a combination of scientific/technological solutions, societal solutions (e.g. politics) and individual behavior (e.g. reducing consumption) is required. Therefore, to answer students' questions on the possible Solutions to climate change, considering these different aspects is important. As was discussed in the previous section, technological developments play their part, but individual (e.g. psychological), economic, regional and political aspects also play a major role. As an example, nations (especially smaller ones) have a limited capacity to act individually, because their economy is tied to the global economy, making global agreements on climate change mitigation important. So, as has been highlighted by Stevenson (1987; 2007), understanding how governments operate, is important in environmental education. One way to bring forth this conversation would be to examine timely issues, such as the Paris 2015 agreements, and how hard, yet important, such global agreements are. Furthermore, education should examine the impact of individuals' mitigative actions on society. As an example, when individuals start changing their consumption patterns from an environmentally harmful product to a friendlier product, the rule of supply and demand will start to bring down the price of the environmentally friendly product, making it more appealing to the general public. This has already been seen in the decrease in prices of solar panels and wind turbines (Hirth, 2013).

In order to address questions related to the Effects on humans, it is crucial to understand that climate change will affect different countries and groups of people in different ways and intensity (see IPCC, 2014), and that the environmental, societal and economic effects are strongly linked to each other. As an example, some regions will not be affected by the environmental changes as strongly as others. This may decrease their willingness to take mitigative actions and instead, focus solely on economic growth. However, by choosing to focus on economic growth, the country may need to increase their fossil fuel consumption, further contributing to climate change. In another region, this may lead to more severe effects of climate change, leading to people leaving their homes as climate refugees. A mass migration of climate refugees will then impact even those countries that were not directly impacted by the environmental changes caused by climate change. As this example shows, and as Andrey and Mortsch (2000) have also discussed, climate change is a global issue where different individuals and countries are affected in different ways, yet all are affected. Also in this regard, systems thinking is needed to be able to understand how climate change affects humans.

\section{Addressing Individual Aspects:}

Students also asked questions related to them as individuals and as members of a society. Some students wanted to know how to Raise Awareness and others, how to act more responsibly (i.e. Practical Solutions).

When it comes to personally responsible actions, students should be given the opportunity to examine their behavior and look for alternative ways of doing things. Such self-reflection can help students grow in action competence (Jensen \& Schnack, 2006)) and understand what type of actions they would be ready to take. This reflection also opens up room for discussing the relationship between knowledge and behavior. Earlier research has shown that providing people with knowledge on environmental issues will not directly translate into a change in attitude and behavior, but rather, human behavior is affected by a multitude of different aspects, including values, altruism, convenience and economy (Kollmuss \& Agyeman, 2002). Understanding this is especially important for those students who want to raise awareness of others. It is also important for them to understand that individual actions tend to revolve around actions with "low-impact", such as recycling (Steg \& Vlek, 2009). One reason for this may be that individuals consider certain actions, such as recycling, 
to have a larger impact on the environment than they actually do (Skamp, Boyes \& Stanisstreet, 2013). Therefore, when considering how to raise the awareness of others, it is important to know which "high-impact" actions students are least aware of. A recent study by Skamp et al. (2013) suggests that one area worth targeting is the impact of meat consumption, as students are relatively unaware of its impacts, yet they seem relatively willing to take action to reduce their meat consumption. However, environmental impact should not be the only measure by which the benefits of different actions are analyzed, as some actions may empower students to take more significant actions in the future.

Finally, it is important for students to understand that people take actions in different ways. Some take personally responsible actions, such as riding a bike, while others take socially responsible actions or future oriented actions (Vesterinen, Tolppanen \& Aksela, 2016). However, as these are very different in nature, comparing them with each other is problematic. Therefore, for students to understand the practical solutions to climate change mitigation, it is important that they do not seek one single answer only, but see the solutions as an array of different actions that can be taken, some fitting one's personal life better than others. More important than taking a certain "right action", it is important to build a mindset of constant reflection, which then helps re-orient one's own actions.

\section{Addressing Aspects of Values:}

The questions demonstrate that students want to know the most effective solutions for climate change mitigation. However, as climate change mitigation is a wicked problem (see Levin, Cashore, Bernstein \& Auld, 2012), society does not yet know the best actions, or even understand the full nature of the problem we are facing. Each action or non-action will have some positive and some negative effects. As Sterling (2010) had discussed, students should understand the sense of urgency, yet critically analyze the actions that are taken. In order to do this holistically, students should simultaneously consider the three dimensions of sustainable development: the environment, the society and the economy. For instance, something that has a fast positive effect on the environment may have a big negative effect on the economy, especially to people living in a certain region or working in particular industries. For instance, unemployment rates may rise rapidly, which tend to lead to other societal challenges, such as insurgencies (Campante \& Chor, 2012). On the other hand, making changes slowly may cause further environmental degradation, causing economic and societal problems in the long run. Therefore, depending on what one values and which region of the world one comes from, different solutions may be considered to be the best. In order for students to gain a holistic view on climate change and climate change mitigation, the underlying ethical issues and different viewpoints of people should be understood.

Students' questions also show that they are unsure about whether climate change is human-induced. Hence, in addition to discussing the scientific phenomena and the NOS, it is important for students to understand that their own views will easily be influenced by others (McKenzie-Mohr, 2013). As climate change is a media issue (see Schreiner et al., 2005), students are constantly being influenced by the values of those media channels and the people who write them. Educational researchers have been discussing the importance of increasing students' media literacy and critical thinking (Hodson, 2011). In climate change education, this should also mean students trying to look, not only into the trustworthiness of the statements, but also into the values of those making these statements: A solution that benefits a certain country or a certain company, may not have global benefits.

\section{A pedagogical approach to addressing students' questions}

In order to address students' questions holistically and to support students' development into systemic thinkers, we argue that, rather than giving direct answers to students' questions, the teacher should direct the students towards guided inquiry: a process in which students attain knowledge from several 
sources and examine their questions from different perspectives (see Kuhlthau, Maniotes, \& Caspari, 2015. A teacher with sufficient content knowledge on climate change may guide this inquiry process by first asking the student questions that help break down their original question into smaller questions, and then directing them to look at the big picture again. An imaginary guided inquiry conversation between a teacher and a student may proceed like this:

Student: How can we make renewable energy sources cheaper and more available to the public?

Teacher: What do you think affects the price of renewable energy sources, or any product for that matter?

\section{(After some research)}

Student: Price is affected by supply and demand, as well as by the price of raw materials and production cost.

Teacher: How could the supply and demand of renewable energy sources be affected?

Student: We would either need more companies producing renewable energy or more people using it.

Teacher: How could the government impact the amount of companies producing renewable energy?

Student: They could give them money to produce renewable energy

Teacher: Yes, they could, and this would bring down the price of renewable energy. And what would happen then?

Student: As the price comes down, people would start to use it more.

Teacher: Yes, and what will this do to the production of renewable energy sources, such as solar panels?

Student: More will be produced, making production cheaper.

Teacher: Yes, so it seems that by giving government support to certain companies, the use of renewable energy could be increased. Now why would governments want to support companies and where would the money come from?

As the example shows, a guided inquiry process can be directed towards dealing with several important issues related to climate change, which were not explicitly present in the student's original question. Furthermore, guided inquiry can be used to expand the discussion beyond the obvious, but overly simplistic conclusions that may first come to mind. By doing so, the teacher may help the students understand how complex an issue climate change and climate change mitigation and adaptation are. Most importantly, guided inquiry is a stepping stone to systems thinking as it helps the student expand their thoughts on an issue or question, by forcing them to examine related components. With practice, the student may learn to ask themselves similar questions to what their 
teacher would ask. Mastering such `self-guided enquiry` would help a student attain the knowledge needed to build 'the big picture', needed for systems thinking.

During the process of guided inquiry, there are several aspects that should be considered to help ensure that the issue is dealt with holistically. To help in this process, it is useful to ask the following questions during the guided inquiry process:

1. How is this question related to climate change science and technological innovation?

2. How is this question linked to society e.g. politics and economy?

3. How is this question related to individual behavior e.g. psychology and ethics?

To deal with the questions holistically, it is then important to examine how the answers to these three questions are linked to each other. As an example, one could examine how the students original question is linked to technological innovation (question 1) and how that is then linked to individual behavior (question 3).

Furthermore, implementing student-centered project-based approaches would give students time to dig deeper into an area of climate change, which most interests them (Krajcik, Blumenfeld, Marx, \& Soloway, 1994). However, as the students' questions suggest, the projects should be crossdisciplinary, organized together with several subject teachers. In a case study conducted by Tolppanen and Tirri (2014), such a project was implemented in a non-formal education program over a period of two months. During this process, students had a mentor who helped the students construct their understanding of the topic by guiding them to research articles, internet resources and to experts. Research on the working-process shows that such a process is meaningful for learning (Tirri, Kuusisto, \& Aksela, 2013) and that the students enjoyed the process (Tolppanen \& Aksela, 2013). After completing the projects, the groups presented their work to each other, permitting them to learn from each other (Tolppanen \& Aksela, 2013). In collaboration with different subject teachers, such a project could also be implemented into schools. In such projects, teachers should guide the students to use both local and global databases when examining the effects of and solutions to climate change.

Earlier research has suggested that dialogues and debates should be used to help students construct their own ideas on environmental issues (González-Gaudiano \& Meira-Cartea, 2010; Zeidler \& Nichols, 2009). However, we would argue that debates on climate change and climate change mitigation will not benefit the learners, unless a deep understanding on the issue has already been reached. The reason for this is that unless the multifaceted nature of climate change is understood, opinions will often be simplistic and inaccurate. Disseminating such ideas in an environment where no one else has sufficient knowledge to counter the claims, the perpetuate misconceptions may stick as truths. However, debates could be a useful tool towards the end of a learning module, as they give the opportunity for students to discuss what they have learned. Furthermore, if the teacher has a sufficient level of content knowledge on climate change, student debates can help the teacher see some of the misconceptions that the students still hold about climate change and climate change mitigation.

\section{Limitations of the Study}

Firstly, the participants in this study come from various backgrounds and therefore the student's previous climate change education differs from each other's. Within the limits of this study, it was impossible to consider how these different backgrounds affect what students find relevant in climate change education, but it may be assumed that previous knowledge does influence the type of 
questions students ask. However, as climate change is a media issue, similar background differences would be found in any given heterogeneous classroom. Though the questions within any given classroom may differ, this study shows that the range of questions is wide, and that answering students' questions is not a simple task, but requires a holistic, multidisciplinary approach.

Secondly, the participants in this study were presumably all scientifically oriented and interested in climate change. Due to student's scientific orientation, the quantity of different types of questions may be different in a more heterogeneous group. However, as the primary focus of this study was on the qualitative nature of the questions, students specific interest towards science is not a limitation to the transferability of the findings. A bigger limitation is the fact, that the questions analyzed in this study are asked by students interested in climate change. It is obvious that in a heterogeneous classroom, not everyone will be interested in climate change, nor be able to ask such diverse questions about climate change, as was seen in this study. Therefore, not all the aspects of a holistic approach or the suggested pedagogical methods can be applied. In such cases, a teacher needs to use their pedagogical skills to examine how the content and methods could be applied to such students. Due to these limitations, further empirical studies are needed on how well the holistic approach suits classroom practice. The authors realize that changing pedagogical practice may bring problems that are not considered in this paper, and that suggestions presented in this paper will not solve the structural problems present in schools (see: Stevenson 1987; 2007). Furthermore, if a national curriculum does not see the importance of dealing with climate change from an individual, societal and vocational perspective, teachers may also lack the motivation to do so. Therefore, the relevance of climate change education needs to be considered also by curriculum developers.

\section{CONCLUSIONS}

This paper first outlines some of the structural, pedagogical and content challenges of climate change education. Based on the Climate System theoretical framework, we argue that a systemic approach is called for in climate change education. This argument is supported by the results of this study, which reveal that students ask a diverse array of questions that are multidisciplinary in nature. This array of questions represents the same themes as those identified in the literature as important for climate change education. Based on this link between theory and practice, we argue that students should be given more opportunities to explore answers to their own questions through a process of teacher guided inquiry.

The paper also highlights the challenges involved in responding to students' climate change questions. One of the main challenges is that climate change is a complex issue involving environmental, cultural and political understandings and values that are partly reflected in students' questions which often touch on several different aspects simultaneously. Addressing these questions requires multidisciplinary pedagogical approaches that promote student inquiry and systems thinking. However, implementing such approaches is typically made difficult by the dominant historical purposes and structures of school systems (see Stevenson, 2007) and a current climate of narrow accountability measures. Therefore, to advance climate change education, more research is needed on how governments, principals and teachers can help ease the tension between old educational structures and new pedagogical approaches. 


\section{References}

Aguiar, O., Mortimer, E. \& Scott, P. (2010). Learning from and responding to students' questions: the authoritative and dialogic tension. Journal of research in science teaching, 47(2), 174-193.

Andersson, B., \& Wallin, A. (2000). Students' understanding of the greenhouse effect, the societal consequences of reducing $\mathrm{CO} 2$ emissions and the problem of ozone layer depletion. Journal of Research in Science Teaching, 37(10), 1096-1011.

Andrey, J., \& Mortsch, L. (2000). Communicating about climate change: Challenges and opportunities. In D. Scott, B. Jones, J. Andrey, R. Gibson, P. Kay, L. Mortsch \& K. Warriner (Eds.), Climate change communication. Proceedings from an international conference (pp. 111). Kitchener-Waterloo: University of Waterloo and Environment Canada.

Bell, R. L. and Lederman, N. G. (2003), Understandings of the nature of science and decision making on science and technology based issues. Sci. Ed., 87: 352-377

Boyes, E., \& Stanisstreet, M. (2012). Environmental education for behaviour change: Which actions should be targeted? International Journal of Science Education, 34(10), 1591-1614.

Campante, F. R., \& Chor, D. (2012). Why was the Arab world poised for revolution? Schooling, economic opportunities, and the Arab Spring. The Journal of Economic Perspectives, 167-187.

Center for Climate Change and Energy Solutions. (2015). Outcomes of the U.N Climate Change Conference in Paris: 21st Session of the Conference of the Parties to the United Nations Framework Convention on Climate Change (COP 21). Retrieved 6/2016 from: http://www.c2es.org/docUploads/cop-21-paris-summary-02-2016-final.pdf

Chin, C., \& Osborne, J. (2010). Students' questions and discursive interaction: Their impact on argumentation during group discussions in science. Journal of Research in Science Teaching, 47(7), 883-908.

Cohen, J. (1960). A coefficient of agreement for nominal scales. Educational and Psychological Measurement, (20), 37-46.

Cohen, L., Manion, L., \& Morrison, K. (2007). Research methods in education. London: Routledge.

Commoner, B. (1972). A bulletin dialogue on" the closing circle," response. Bulletin of the Atomic Scientists, 28(5), 42-56.

Demirdogen, B., \& Cakmakci, G. (2014). Investigating students' interest in chemistry through selfgenerated questions. Chemistry Education, Research and Practice, 15, 192-206.

Ehrlich, P. R., \& Holdren, J. P. (1971). Impact of population growth. Science, 171, 1212-1217.

Finnish National Board of Education. (2014). National Core Curriculum for Preparotory education for upper secondary education. Tampere: Suomen Yliopistopaino. 
Finland's Science Education Centre. (2012). Millennium Youth Camp. Retrieved 12/9/2014 from http://www.helsinki.fi/luma/english/millennium-youth-camp

Flood, R. (2001). 'The Relationship of "Systems Thinking” to Action Research'. In: Reason, P. and Bradbury, H. (Eds.) Handbook of Action Research - Participative Practice and Enquiry. London: Sage Publications.

Goldberg, M. (2001). US Federal Energy Subsidies: Not all technologies are created equals. Advances in solar energy, 14, 361-384.

González-Gaudiano, E., \& Meira-Cartea, P. (2010). Climate change education and communication. In F. Kagawa, \& D. Selby (Eds.), Education and climate change: Living and learning in interesting times (pp. 13-34). New York: Routledge.

Graesser, A., \& Person, N. (1994). Question asking during tutoring. American Educational Research Journal, 31(1), 104-137.

Hirth, L. (2013). The market value of variable renewables: The effect of solar wind power variability on their relative price. Energy economics, 38, 218-236.

Hodson, D. (2008). Towards scientific literacy: A teacher's guide to the history, philosophy and sociology of science. Rotterdam, Netherlands: Sense Publishers.

Hodson, D. (2011). Looking to the future: Building a curriculum for social activism. Rotterdam, Neatherlands: Sense Publishers.

Hynes, P. (1993). Taking population out of the equation: Reformulating I= PAT. USA: North Amherst Massachusetts Institute on Women and Technology. Retrieved from http://www.readingfromtheleft.com/PDF/IPAT-Hynes.pdf on 11/2014.

IPCC. (2014). Summary for policymakers. In Field, C.B., V.R. Barros, D.J. Dokken, K.J. Mach, M.D. Mastrandrea, T.E. Bilir, M. Chatterjee, K.L. Ebi, Y.O. Estrada, R.C. Genova, B. Girma, E.S. Kissel, A.N. Levy, S. MacCracken, P.R. Mastrandrea, and L.L. White (Ed.), Climate change 2014: Impacts, adaptation, and vulnerability. Part A: Global and sectoral aspects. Contribution of working group II to the fifth assessment report of the intergovernmental panel on climate change. (pp. 1-32). Cambridge, United Kingdom and New York, NY, USA: Cambridge University Press.

Jensen, B. B., \& Schnack, K. (2006). The action competence approach in environmental education: Reprinted from Environmental Education Research (1997) 3 (2), pp. 163-178. Environmental education research, 12(3-4), 471-486.

Jonassen, D. H. (2000). Revisiting activity theory as a framework for designing student-centered learning environments. In D. H. Jonassen, \& S. M. Land (Eds.), Theoretical foundations of learning environments (pp. 89-121). Mahwah, New Jersey: Lawrence Erlbaum Associates.

Kollmuss, A., \& Agyeman, J. (2002). Mind the gap: Why do people act environmentally and what are the barriers to pro-environmental behavior? Environmental Education Research, 8(3), 239260. 
Krajcik, J. S., Blumenfeld, P. C., Marx, R. W., \& Soloway, E. (1994). A collaborative model for helping middle grade science teachers learn project-based instruction. The Elementary School Journal, 94(5), 483-497.

Kuhlthau, C. C., Maniotes, L. K., \& Caspari, A. K. (2015). Guided Inquiry: Learning in the 21st Century: Learning in the 21st Century. ABC-CLIO.

Levin, K., Cashore, B., Bernstein, S., \& Auld, G. (2012). Overcoming the tragedy of super wicked problems: constraining our future selves to ameliorate global climate change. Policy Sciences, 45(2), 123-152.

Lombardi, D., \& Sinatra, G. M. (2013). Emotions about teaching about human-induced climate change. International Journal of Science Education, 35(1), 167-191.

McKenzie-Mohr, D. (2013). Fostering sustainable behavior: An introduction to community-based social marketing. New society publishers.

Mitchell, I., (2010). The Relationship between Teacher Behaviours and Student Talk in Promoting Quality Learning in Science Classrooms. Research in Science Education, 40(2), 171-186.

Ocal, A., Kisoglu, M., Alas, A., \& Gurbuz, H. (2011). Turkish prospective teachers' understanding and misunderstanding on global warming. International Research in Geographical and Environmental Education, 20(3), 215-226.

Papadimitriou, V. (2004). Prospective primary teachers' understanding of climate change, greenhouse effect, and ozone layer depletion. Journal of Science Education and Technology, 13(2), 299-307.

Pruneau, D., Moncton, U., Liboiron, L., \& Vrain, E. (2001). People's idea about climate change: A source of inspiration for the creation of educational programs. Canadian Journal of Environmental Education, 6(1), 58-76.

Ratinen, I. 2016. Primary student teachers'climate change conceptualization and implementation on inquiry-based and communicative science teaching: A design research (Doctoral Thesis). University of Jyväskylä. Jyväskylä Studies in Education, Psychology and Social Research.

Salonen, A. O. (2010). Kestävä kehitys globaalin ajan hyvinvointiyhteiskunnan haasteena. [Sustainable development as the challenges of a welface society in a global world]. (Doctoral dissertation) Tutkimuksia 318. Helsinki: Yliopistopaino.

Schreiner, C., Henriksen, E., Kirkeby, H., \& Pål, J. (2005). Climate education: Empowering today's youth to meet tomorrow's challenges. Studies in Science Education, 41(1), 3-49.

Seiffert, M. E. B., \& Loch, C. (2005). Systemic thinking in environmental management: support for sustainable development. Journal of cleaner production, 13(12), 1197-1202.

Shepardson, D. P., Niyogi, D., Choi, S., \& Charusombat, U. (2009). Seventh grade students' conceptions of global warming and climate change. Environmental Education Research, 15(5), 549-570. 
Shepardson, D. P., Niyogi, D., Roychoudhury, A., \& Hirsch, A. (2012). Conceptualizing climate change in the context of a climate system: Implications for climate and environmental education. Environmental Education Research, 18(3), 323-352.

Skamp, E., Boyes, E., \& Stanisstreet, M. (2009). Australian secondary students' views about global warming: beliefs about actions, and willingness to act. Research in Science Education, 39 (5), 661-680.

Skamp, K., Boyes, E. \& Stanisstreet, M. (2013). Beliefs and willingness to act about global warming: Where to focus science pedagogy? Science Education, 97(2), 191-217.

Steg, L., \& Vlek, C. (2009). Encouraging pro-environmental behaviour: An integrative review and research agenda. Journal of environmental psychology, 29(3), 309-317.

Sterling, S. (2004). Higher education, sustainability, and the role of systemic learning. In Higher education and the challenge of sustainability (pp. 49-70). Springer Netherlands.

Sterling, S. (2010). Learning for resilience, or the resilient learner? Towards a necessary reconciliation in a paradigm of sustainable education. Environmental Education Research, 16(56), 511-528.

Stevenson, R. B. (1987/2007). Schooling and environmental education: Contradictions in purpose and practice. In I. Robottom (Ed.) Environmental education: Practice and possibility. Geelong, Victoria: Deakin University Press. Reprinted in Environmental Education Research, 13(2), 139-153.

Stevenson, R. B. (2007). Schooling and environmental/sustainability education: From discourses of policy and practice to discourses of professional learning. Environmental Education Research, 13(2), 265-285.

Svihla, V., \& Linn, M. C. (2012). A design-based approach to fostering understanding of global climate change. International Journal of Science Education, 34(5), 651-676.

Tilbury, D., \& Cooke, K. (2005). A national review of environmental education and its contribution to sustainability in Australia: frameworks for sustainability. Canberra: Australian Government Department of the Environment and Heritage and Australian Research Institute in Education for Sustainability.

Tirri, K., Kuusisto, E., \& Aksela, M. (2013). What kind of learning is meaningful and interactive to gifted science students? A case study from millennium youth camp. In K. Tirri, E. Hanhimäki \& E. Kuusisto (Eds.), Interaction in educational domains Rotterdam: Sense Publishers.

Tirri, K., Tolppanen, S., Aksela, M., \& Kuusisto, E. (2012). A cross-cultural study of gifted students' scientific, societal, and moral questions concerning science. Education Research International, 2012, 1-7.

Tolppanen, S., \& Aksela, M. (2013). Important social and academic interactions in supporting gifted youth in non-formal education. LUMAT, 1(3), 279-298. 
Tolppanen, S., \& Tirri, K. (2014). How an enrichment summer program is meeting the expectations of gifted science students: A case study from Finland. International Journal of Talent Development and Creativity, 2(1), 103-115.

Vesterinen, V-M., Tolppanen, S., \& Aksela, M. (2016). Towards Citizenship Science Education: What Students do to make the World a Better Place? International Journal of Science education. 38(1), 30-50.

World Commission on Environment and Development. (1987). Our common future. Oxford: Oxford University Press.

Zeidler, D. L., \& Nichols, B. H. (2009). Socioscientific issues: Theory and practice. Journal of Elementary Science Education, 21(2), 49-58. 



